\title{
How Have Consumers Fared in Bank Privatization? International Evidence
}

\author{
Anthony Q. Q. Aboagye \\ Associate Professor, Department of Finance, University of Ghana, Ghana \\ Tel: 233-24-425-2596 E-mail: qaboagye@ug.edu.gh \\ Isaac Otchere (Corresponding author) \\ Professor, Sprott School of Business, Carleton University \\ 1125 Colonel By Drive, Ottawa, Ontario, K1S 5B6, Canada \\ Tel: 1-613-520-2600 ext. 2731 E-mail: isaac_otchere@carleton.ca
}

Received: September 29, 2012

Accepted: November 12, 2012 Online Published: December 16, 2012

doi:10.5430/ijfr.v4n1p29

URL: http://dx.doi.org/10.5430/ijfr.v4n1p29

\begin{abstract}
We examine whether consumers have benefited from bank privatization worldwide and find that bank spreads are significantly higher in the post privatization period than in the pre-privatization period, suggesting that bank customers have not benefited from bank privatization. However, we observe that the increase in net interest margin occurred in the developed countries whereas consumers in developing countries have benefited from reduced bank margins following privatization. Despite the reduction in bank margins, consumers in developing countries still pay more for banking services than their counterparts in the developed world. Since developed countries banking environment is more competitive, lack of competition does not seem to explain our findings. Rather, the results appear to support the conjecture that margins were perhaps kept artificially low in the pre-privatization period and that the higher margins in the developed countries reflect market conditions.
\end{abstract}

Keywords: Bank, Privatization, Net interest margin, Bank spread, Consumers

\section{Introduction}

Bank privatization is a tool used by policy makers to foster competition in the financial services sector. Among the reasons why governments privatize state-owned banks and state-owned enterprises in general is the desire to promote efficiency and the opportunity to introduce competition. (Note 1) It is expected that once privatized, the pressures of product market competition may compel the newly privatized firms to operate more efficiently if they are to survive in the post privatization period (Otchere, 2007). As a result of the large-scale privatization programs that have taken place around the world, there has been an intense research interest in privatized firms. Most often, the goal of this research has been to examine the post-privatization and stock market performance of privatized firms. There is overwhelming evidence at the firm level that privatization leads to improvement in operating performance of privatized firms (Megginson et al, 1995 and Boubakri et al, 1998) and stock market performance (Megginson et al, 2000; Boehmer et al 2005, Otchere 2007). Otchere (2009) has documented similar results for banks.

While previous bank privatization research has focused on micro issues such as the performance of privatized banks, an area of inquiry that has not received much attention in the literature is the real effects of bank privatization on consumers. One of the reasons for bank privatization is to foster competition in the industry which in theory is expected to benefit consumers, yet we do not know whether consumers have benefited from the large scale bank privatizations that have taken place around the world as we have little or no research that investigates how consumers have fared. Therefore, in contrast to previous research that focuses on the operating and stock market performance of privatized banks, in this study, we investigate how consumers have fared in bank privatization by examining whether privatization, and the attendant increase in competition lead to lower cost of borrowing and/or an increase in deposit rates, and hence a narrowing of interest rate margins. 
Bank privatization and the attendant liberalization of financial markets lead to more competition. The banking environment becomes contestable following privatization as the entry of foreign banks stimulates competition. Competitive pressures could compel banks to increase deposit rates and/or reduce lending rates, thus culminating in the narrowing of bank spread. Consumers could thus benefit from the availability of financial services at reasonable cost. On the other hand, greater competition can highlight deficiencies that raise the cost of financial intermediation as threatened banks could increase lending rates and or/reduce deposit rates to survive. Also, it is possible that increased competition can have adverse effects on access to financial services as it can undermine the incentives of banks to invest in information acquisition and thereby lowering lending to information intensive borrowers (Claessens et al, 2009). This is especially so in developing countries where, due to institutional weaknesses such as poor informational and institutional infrastructure and weak contracting environment, the degree of contestability is low and access to credit by some segments of the society is limited. As competition intensifies in such an environment, profitability may suffer and banks may have little incentive to invest in long term relationship-based lending and information necessary for lending to small and medium size customers (Claessens et al, 2009). It is also worth noting that state control of banks in a repressed economic environment may have kept margins artificially narrow in the pre-privatization period, in which case interest rate margins can widen in the post privatization period. Thus, whether or not consumers have benefited from bank privatization is an empirical question. We examine the key question of whether consumers have benefited from banking privatization with a focus on developing and developed countries since the institutional environment and the extent of competition in the banking sectors in these countries are different.

We find that for our sample of privatized firms the median post-privatization NIM is significant higher than the pre-privatization NIM, suggesting that on the whole, bank customers have not benefited from bank privatization. However, we observe differential effects of bank privatization on consumers. The NIM for developing countries has reduced in the post privatization period whereas that of the developed countries has increased. Thus, the finding that consumers have not fared well applies more to those in the developed countries. Despite the drop in bank margin, consumers in the developing countries still pay more for banking services than their counterparts in the developed world as the banks in the developing countries have higher margins in the post privatization period than those in the developed countries. However the difference in NIM between the two sub-samples is smaller in the post privatization period than in the pre-privatization period suggesting that bank customers in developing countries now enjoy lower margins. The difference in the observed margins could be explained by the degree of competition. However, it is worth noting that the banking sector in the developed countries was more competitive even in the pre-privatization period than in the developing countries. Thus, lack of competition does not explain our main finding of increase in NIM in the post privatization period. Rather, the results appear to support the conjecture that perhaps margins were kept artificially low in the pre privatization period and that the higher margins in the developed countries reflect market conditions.

Our cross sectional analysis of net interest margin shows that banks with higher operating expenses have higher net interest margins suggesting that consumers would benefit more if they dealt with banks with lower operating margins. If that were to happen more banks would find themselves having to lower their operating expenses further in other to win more customers. We also find that banks with higher equity relative to total assets charge higher margins. This implies customers who want better protection must be prepared to pay for same in the form of wider margins. The same argument holds for liquidity of privatized banks, namely higher liquidity comes at the expense of higher margins. Further, we find that improved managerial efficiency has tended to benefit consumers in the form of lower margins. Banks with higher credit risk have a tendency to charge higher margins.

Our study contributes to the literature in different ways. While filling a gap in the literature, the questions investigated in this study will serve policy makers' interest. First, our study explores an area that has thus far not received attention in the privatization literature, namely how consumers have fared in bank privatization. The literature on privatization has mostly been concerned about the context within which privatization takes place and the long-term performance of privatized banks. Most prior studies focusing on the financial effects of privatized firms by examine the pre and post privatization operating performance of privatized firms. We investigate the 'real effects' of bank privatization on consumers by examining whether consumers have benefited from bank privatization. Our study thus contributes to the privatization literature by advancing our knowledge of the impact of privatization programs. A detailed cross-country analysis of how consumers have fared from banking privatization will thus be a welcome addition to the scholarship on the economics of privatization. Second, from a policy implication perspective, the study adds another dimension to the documented effects of privatization, i.e., it shows whether consumers have fared better in banking privatization. The results will be relevant to policy makers and governments around the world, 
international lending agencies such as the IMF and the World Bank that have had privatization as part of the policy prescriptions under the Structural Adjustment Programs (SAPs).

\section{Brief Background and Hypotheses Development}

\subsection{Brief Background}

Privatization has become a popular means of restructuring state enterprises in both developed and developing countries. Bortolotti et al. (2001) report that from 1977 to 1999, privatization of state-owned enterprises involved 2,457 deals in 121 countries. Bank privatizations have featured prominently in this wave. Berger et al. (2005) find that state-owned banks that are usually chosen for privatization have performed poorly in the past. Governments have found the solution to the performance problems and financial woes of state enterprises in privatization. (Note 2) There is evidence that in developed countries, bank privatization improves performance (Otchere and Chan (2003) and Otchere (2009)). For developing countries however, the evidence is mixed. While Beck et al. (2005) document a significantly positive impact of privatization for banks privatized in Nigeria; Otchere (2005) finds marginal improvements in the performance of privatized banks in middle- and low-income countries.

Megginson (2005) reviewed studies on bank privatization and found that state-owned banks are less efficient than privately owned banks, and that state domination of banking imposes increasingly severe penalties on those countries with the largest state banking sectors. He found little evidence that privatization by itself is enough to transform the efficiency of privatized banks. The evidence catalogued in Megginson (2005) indicates that the performance of privatized banks in transition economies of Central and Eastern Europe and the former Soviet Union has been somewhat more favorable than that in non-transition developing countries. La Porta et al. (2002) examined the importance and impact of state ownership of banks in 92 countries and found that government ownership of banks retards financial system development and restricts economic growth rates. Bonin et al. (2002) also examined the impact of ownership structure (state, private and foreign ownership) on bank performance in six transition economies and found robust evidence of higher profitability for fully private banks than for banks with some state ownership. Cornett et al. (2003) investigated differences in performance between privately-owned and state-owned banks in 16 Far East countries from 1989 through 1998. They found that state-owned banks are significantly less profitable than privately-owned banks. Otchere (2005) also found that privatized banks underperform in the long run. However, he documented marginal improvements in post-privatization operating performance of privatized banks.

Prior to privatization, the degree of contestability in the banking sector is usually low. Limiting entry of new banks and the implicit and explicit restrictions on bank activities are associated with higher bank margins. In a theoretical paper Besanko and Thakor (1992) analyze the consequences of relaxing entry barriers and find that equilibrium loan rates decline and deposit interest rates increase following the entry of foreign banks. Barth, Caprio and Levine (2003) show, among others, that tighter entry requirements are negatively linked to bank efficiency, leading to higher interest rate margins and overhead expenditures. The tighter entry restrictions limit competition and the contestability of a market and affect bank efficiency (Claessens, 2009). The entry of foreign banks (following the relaxation of entry barriers) has been found to have generally favorable competitive effects on the development and efficiency of domestic banking systems (Chopra, 2007). It has been argued that the pressures of product market competition may also compel the newly privatized banks to operate more efficiently, aggressively and competitively if they are to survive in the post privatization period (Otchere, 2007). Competitive pressures resulting from privatization are expected to force down margins as lending rates decrease and deposit rates increase, thus lowering the cost of financial intermediation. Despite the large scale privatization of state-owned banks and the myriad of research that examines the performance of privatized banks, we still do not have a full understanding of how consumers have fared in banking privatization. This paper takes the next important step in providing evidence on how consumers have fared in bank privatization.

\subsection{Hypotheses}

In this paper, we address two main hypotheses. First, we test the hypothesis that consumers have benefited from privatization. Privatization and the attendant liberalization of financial markets lead to more competition. The banking environment becomes contestable. The entry of foreign and/or newly formed private banks will stimulate competition and lead to an improvement in the quality of local banks. It is reasonable to surmise that a consequence of relaxing entry barriers and fostering competition in the banking sector is that lending rates will decrease, thus lowering the cost of financial intermediation as competitive pressures are put on existing banks. Narrow margins in the post-privatization period will be consistent with the hypothesis that consumers have benefited from the availability of financial services at reasonable cost. On the other hand, it is possible that state control of banks in repressed economic environments could have kept margins artificially narrow in the pre-privatization period. Moreover, it is 
possible that competition could actually increase margins in the post privatization period. In a competitive banking environment, bank profitability may suffer and that when faced with increased competition, threatened privatized banks, which had hitherto enjoyed government controlled rents, may attempt to recover lost subsidies by increasing lending rates and or/reducing deposit rates.

Second we test the hypothesis that consumers in developed countries have fared differently than those of the developing countries. Prior bank privatization studies (including Otchere, 2009) show significant differences in the long-term performance of privatized banks in these countries. Also, there is evidence that the banking system in developing countries are oligopolistic (dominated by a small number of banks), hence profit maximization competitive behavior by commercial banks could lead to increased spread between lending and deposit rates without increased financial deepening in these countries (Demetriades and Luintel, 1996). Furthermore, there are significant differences in the incentives behind bank privatization in developing and developed countries. Unlike developed countries that carried out bank privatization out of their own volition and where the banking sector was relatively competitive prior to privatization, developing countries embarked upon extensive financial reforms sometimes following intense prodding by the IMF/World Bank, and their banking sector was dominated by state banks. The reforms package adopted by the developing countries usually included the privatization of banks and the attendant relaxation of entry barriers. In developed countries (which are characterized by liquid markets and low transaction costs), privatization could have little impact on observed spreads. In developing countries that are characterized by thin markets, interest rate margins could be wider in the pre-privatization period, thus spreads could reduce in the post privatization period. It is also possible that state control of banks in a repressed economic environment may have kept margins artificially narrow in the pre-privatization period, in which case interest rate margins can widen in the post privatization period when the market is liberalized. (Note 3) It is also reasonable to surmise that as a result of increased competition, threatened banks could increase lending rates and or/reduce deposit rates, in order to survive particularly so in an oligopolistic environment of the developing country banking sector. Given the difference in the institutional characteristics in developed and developing countries, one would expect a larger drop in margins for banks in developing countries.

\section{Data and Methodology}

\subsection{Data}

We obtained our initial sample of privatized banks from Megginson (2005) and the World Bank privatization database. Income statement and balance sheet data were obtained from Datastream and Bloomberg databases. For each bank we extracted annual data covering five years prior to privatization and five years after privatization. In addition to bank specific variables, we obtained from World Development Indicators and International Finance Statistics databases economy wide variables including bank total assets /gross domestic product, volatility of annual Treasury bill rates and annual inflation rate. (Note 4)

Table 1 presents data on a number of privatized banks contained in our sample about which Megginson (2005) provides data in respect of amounts raised through privatizing and the proportion of the bank offered for sale. (Note 5) Megginson provides more information on banks located in so called high information countries than banks in other regions. In these high information countries, more money was raised per bank than in any other region. This is followed by the banks located in Latin America, then Eastern Europe and least in Africa. On average, the proportion of bank offered for privatization is highest in Latin America (64.5\%); the fraction of the banks offered for sale in other countries is similar (just above $40 \%$ ).

$<$ Insert Table 1 Here $>$

\subsection{Methodology}

\subsubsection{Measures of Interest Rate Spread}

Our first objective is to analyze whether bank net interest margins change (increased or decreased) after privatization. The spread provides an estimate of the transaction cost borne by consumers. In principle, consumers benefit when the spread is relatively low. It is thus expected that if privatization benefits bank customers, NIM would decrease after privatization. That is, narrow margins may indicate relative competitive banking systems due to low intermediation costs and low regulatory "taxes" (e.g. reserve requirements and capital requirements) typical of banking environments with little government involvement (post liberalization). This view should however be tempered with the observation that state control of banks in repressed economic environment (in the sense of McKinnon-Shaw) prior to privatization may have kept NIM artificially low.

The appropriateness of NIM in measuring interest rate spreads has been discussed in the literature by Brock and 
Rojas-Suarez (2000). The authors argue that NIM excludes fees and commissions that may increase the cost of loans to borrowers and reduce interest received by depositors. As well, by considering all assets (hence all liabilities), NIM deviates from bank marginal costs and revenues. The advantage of this measure however is that, compared to other measures, it can be estimated from bank income statement and balance sheets, and in fact, it is the measure most commonly used in the literature (e.g. Brock and Rojas-Suarez, 2000). We investigate the net interest margin (NIM) of banks defined as the spread between bank interest income and interest expense expressed as a ratio of bank assets. As a test of robustness, we also use another measure of interest rate spread, defined as the ratio of interest income to bank loans, less the ratio of interest expense to bank deposits, which Brock and Rojas-Suarez (2000) consider to be a narrow measure of interest rate spreads.

\subsubsection{Model}

We first conduct standard tests of differences in pre- and post-privatization net interest margins using two measures of central tendency, namely means and medians. Taking the year of privatization as year 0 , we computed for each bank, its annual NIM up to five years prior to privatization and five years after privatization in an effort to approximate long run effects. It is known that means are influenced by outlier observations. They are also sensitive to skewness in the data. Therefore, we also computed median pre- and post-privatization net interest margins for each bank. We then examine the research questions in a more econometrically robust manner using the expanded framework of Ho and Saunders (1981). Their original framework modelled banks as intermediating between depositors and borrowers and deduced that bank margins have two components - the degree of competition and the interest rate risk faced by banks on credits and deposits. Ho and Saunders' (1981) model specifies the dependent variable as some measure of the spread between interest earned by the bank and interest paid out by the bank. The spread is shown to be influenced by the competitive structure of markets, average operating costs, extent of risk aversion, volatility of money market rates, riskiness of a bank's loan portfolio, and the average size of credit and deposit operations. We operationalize the model of Ho and Saunders (1981) as modified by Maudos and Fernández de Guevara (2004) for factors that explain interest rate spreads.

Maudos and Fernández de Guevara derived a bank's end of period wealth as a function of the interest rate risk and credit risk faced by the bank. Broadly, the approach adopted by researchers to these investigations has involved specifying the dependent variable as some measure of the spread between interest earned by the bank and interest paid out by the bank. Assuming banks are maximizers of expected utility, and considering the costs of producing deposits and credits, random arrival of deposits and loan requests, the optimal spread between lending and borrowing rates is shown to have the following determinants: the competitive market structure; average operating costs; extent of risk aversion; volatility of money market rates; riskiness of a bank's loan portfolio; and the average size of credit and deposit operations.

The model is specified as:

$$
\begin{gathered}
\text { NIM }=f(\text { Bank operating costs, Bank credit risk, Degree of bank risk aversion, Quality of bank management, } \\
\text { Size of bank operation, Industry structure, CONTROL). (Note 6) }
\end{gathered}
$$

\subsubsection{Bank Specific Variables}

Bank operating costs. In general, one would expect banks to seek to cover their operating costs by increasing NIM. Thus, this variable should have a positive impact on NIM. Here, bank operating costs is expressed as a ratio of total assets.

Bank credit risk. Banks may compensate for the credit risk they bear by increasing their margins. In this study, bank credit risk is defined as the ratio of bank loans to total assets. In principle, it is the provisions for bad and doubtful loans that more closely suggests the quality of the loan portfolio. Unfortunately, our data sources do not report this variable consistently across time and across banks. The alternate measure we used here was also used by Maundos and Fernández de Guevara (2004).

Degree of bank risk aversion. A more risk averse bank will have more equity in its capital structure to be sure that it has funds against which to write off losses that might occur. Nevertheless, it must earn enough returns to satisfy the higher returns required by shareholders. Consistent with this reasoning, such a bank will charge higher margins. The measure of risk aversion is the ratio of shareholders equity to total assets.

In this implementation this variable serves another purpose: it controls for the impact of individual country regulation in respect of the capital adequacy ratio of banks. (Individual country guidelines may deviate from those proposed by the Basel Committee on Banking Supervision.) 
Quality of bank management. Firms with superior management should be more efficient in managing resources and will thus incur lower costs per unit of revenue, hence possibly higher profits. Thus, the variable that measures bank operating cost per unit of revenue is an indicator of management efficiency. Alternatively, such banks may charge lower margins if efficiency savings are passed on to customers. This may result in such banks gaining large market shares that might result in high levels of concentration. Berger (1995) has suggested that the way to test for these so called efficient structure hypothesis and the collusion hypothesis is by introducing concentration, efficiency, and market share as explanatory variables of relative interest rate margins. We do the same here.

Size of bank operations. Large-scale operations may influence NIM by lowering average costs. As a result, banks may make higher profits. Alternatively, banks may pass on cost savings to customers in the form of lower margins. The usual measures of this indicator are total assets, total deposits or total loans. Our bank data sources (Datastream and Bloomberg) report these variables in local currencies rendering them unsuitable for cross-country analysis such as this. We overcome this hurdle by standardizing the total assets of each bank as the ratio of the gross domestic product (GDP) of each country, also reported in current local currency units by the World Development Indicators.

\subsubsection{Industry Characteristics}

Industry structure: The literature notes that bank profits (margins) are relatively higher in concentrated markets. The usual measure of industry concentration is the Herfindahl-Hirshman index, computed as the sum of the squares of individual bank's market share of total industry assets, deposits or loans. Datastream and Bloomberg do not report industry totals of these variables. The International Finance Statistics (IFS) of the International Monetary Fund does in equivalent United States dollars. While the IFS reports currency exchange rates, we were wary of using these exchange rates to link data from the IFS to Datastream or Bloomberg databases, because of concern that whenever a country adopts a new currency (such as introduction of the euro, or redenomination of a local currency) the IFS reported exchange rates are re-stated backwards to reflect the new currency, but individual bank data reported in Datastream or Bloomberg databases may remain reported in the original domestic currency.

We overcome this challenge by once again using current GDP, reported in domestic currency, to proxy total assets of banks. Thus, the ratio of a bank's total assets to GDP, both reported in local currency, proxy's that banks market share. Granted, GDP and industry total assets are of different magnitudes, but changes in these two measures, which are what are important in regression analyses, are closely related.

Opportunity cost of non-earning bank reserves (primary reserves). In many jurisdictions, banks are required by law to set aside a percentage of the deposits they mobilize as non-earning reserves against contingencies to provide liquidity cushion. Liquidity reserve requirements are a burden on the industry impacting negatively on profitability and must therefore be passed on to customers in the form of wider margins. We measure this variable as the ratio of cash and near cash items to total bank assets. In this implementation, this variable serves another purpose, it controls for the impact of individual country regulation in respect of the primary reserves ratio.

\subsubsection{Economy Wide Variables}

Unstable macroeconomic and policy environment is perceived as more risky and banks may compensate for it by requiring wider margins. Our proxies for the macroeconomic environment in which banks operate are the rates of inflation and the volatility in the Treasury bill rates. The volatility of interest rates is hypothesized to impact bank margins positively as banks may have to borrow to make loans whenever requests for loans arrive and banks do not have enough deposits. Conceivably, other measures of interest rate risk may be used, but for many transition and other developing economies dependable money market rates are not available. Treasury bill rates are the ones most readily available. Higher volatility should translate to higher margins, as will unstable inflation.

\subsubsection{Interaction between Credit Risk and Interest Rate Risk}

It is known in the bank management literature that interest rate risk and credit risk are not uncorrelated. Here we capture this potential relationship by interacting credit risk with interest rate risk measures.

\section{Results}

We present the results of the tests of differences in means and medians for our overall sample and its sub-samples, followed by regression results for factors that explain the net interest margins of banks after privatization.

\subsection{Differences in Means and Medians}

In this study we conjecture on the one hand that as a result of the relaxation of entry barriers and the fostering of competition in the banking sector, lending rates could decrease thus lowering the cost of financial intermediation, and deposit interest rates may increase thereby culminating in the narrowing of spreads as competitive pressures are 
put on existing banks. On the other hand, state control of banks in repressed economic environments could have kept margins artificially narrow in the pre-privatization period. Moreover, it is possible that competition could actually increase margins in the post-privatization period. In a competitive banking environment, bank profitability may suffer, and when faced with increased competition, threatened privatized bank that had hitherto enjoyed monopoly rents may attempt to recoup lost revenues by increasing lending rates and or/reducing deposit rates.

To test this hypothesis, we conducted tests of differences in means and medians between the pre-privatization and post privatization net interest margin for the sample. The results are presented in Tables 2 . We observe that the mean NIM has reduced slightly from the pre-privatization level of $3.3 \%$ to the post privatization period level of $3.2 \%$, but the change is not statistically different from zero. The mean results should however be interpreted with caution because the implicit assumption that the population of sample means is normally distributed may not hold for ratios. We therefore present the results based in median ratios that are also less influenced by outliers. The results show that the post-privatization median NIM of 0.0329 is significantly larger than the pre privatization median NIM of 0.0226 and the difference of 100 basis points is significant at $3 \%$, thus suggesting that net interest margin has increased for our sample of privatized firms.

The results are consistent with the assertion that state control of banks may have kept margins artificially narrow in the pre-privatization period and that the higher post privatization net interest margin could reflect market rates prevailing in the post-liberalized regime. Moreover, the results are also consistent with the conjecture that in the post-privatization competitive banking environment, bank profitability could suffer and that when faced with increased competition, threatened privatized bank which had hitherto enjoyed monopoly status and have now lost government subsidies may attempt to recoup 'losses' by increasing lending rates and or/reducing deposit rates. In any case, the widening of the margins in the post-privatization period is consistent with the hypothesis that for the sample as a whole, consumers have not benefited from the availability of financial services at reasonable cost.

$<$ Insert Table 2 Here $>$

\subsection{Have Consumers in Developed and Developing Countries Fared Differently?}

We hypothesize that the impact of bank privatization on consumers in developed countries could be different from that in the developing countries. There is evidence that the banking systems in developing countries are oligopolistic (dominated by a small number of banks), hence profit maximizing competitive behavior by commercial banks could lead to increased spread between lending and deposit rates without increased financial deepening in these countries (Demetriades and Luintel, 1996). Given the difference in the institutional setup in developed and developing countries, we test whether consumers in the developed countries have fared differently from those in developing countries. The results are presented in Table 3. Panel A shows the mean results while panel B presents the median results. Consistent with the mean results documented for the full sample, we observe that although the mean post privatization NIM for both the developed and developing countries is marginally lower than the pre-privatization NIM, the difference is not statistically different from zero. However, comparing the NIM for the developed countries to that of the developing countries, we observe the mean pre-privatization NIM of $4.5 \%$ for the developing countries is statistically larger than that of the developed countries of $2.7 \%$ at $5 \%$. The difference in the spread can be due to the level of competition in these countries. The banking sector in the developed countries was more competitive in the pre-privatization period than in the developing countries. In the post privatization period, the mean NIM for the banks in the developing countries is still statistically higher; the difference of $1.90 \%$ is statistically significant at $1 \%$ (t-statistic $=4.36$ ).

The median NIM results presented in Panel B also show that for developing countries, the NIM has reduced after privatization whereas the median NIM has increased for the developed countries sample. Similar to the mean results, the median pre-privatization NIM for the privatized banks in developing countries is significantly higher than that in the developed countries. Similarly, the median bank in the developing countries has a higher NIM than that in the developed countries in the post-privatization period. However the difference in NIM between the two sub-samples is smaller in the post privatization period than in the pre-privatization period. The increase in the post privatization NIM observed for the full sample is therefore driven by the developed countries sample. Thus the finding that consumers have not fared well applies more to consumers in the developed countries. Whilst consumers in the developing countries still pay more for banking services than their counterparts in the developed world, the difference has reduced in the post-privatization period.

$<$ Insert Table 3 Here $>$

Examining the NIM in developed and developing countries also allows us to test which of the possible reasons stated 
above actually accounts for the results of the full sample. Recall that for the full sample, the median post privatization NIM is larger than that of the pre-privatization period. The results are consistent with the assertion that state control of banks may have kept margins artificially narrow in the pre-privatization period and that the higher post privatization net interest margin could reflect market rates prevailing in the post-liberalized regime. Alternatively, the results could be due to the fact that the competitive banking environment compelled privatized banks to increase margins to make up for lost subsidies. Or simply the high post privatization margin could be attributed to lack of competition in the post privatization period that allows the privatized banks to increase margins. If indeed the results documented for the full sample are due to lack of competition in the post privatization period, then the privatized firms in the developing countries would have experienced an increase in the post privatization NIM whereas those in developed countries would have experienced a reduction or no change in the measure because the banking environment is competitive. The results do not support this conjecture, as the post privatization NIM for the developed countries sample is higher than that in the pre-privatization period. Because of lack of competition for the LDC, we would expect their NIM to increase but we see that NIM reduces. Similarly, if lack of competition account for the higher net interest margin in the post-privatization period, then the privatized bank in the developing countries would have experienced higher net interest margin. The results however show that the privatized banks in the developing countries rather experienced a reduction in NIM. These results appear to support the conjecture that perhaps margins were kept artificially low in the pre privatization period and that the higher margins in the developed countries reflect market conditions.

\subsection{Cross Sectional Analysis of Net Interest Margin}

To provide more econometrically robust results, we estimate a cross sectional regression of net interest margin on a number of variables using the expanded Ho and Saunders (1981) model. We operationalize the model on three categories of explanatory variables, namely, bank specific variables, banking industry variables and economy wide variables.

\subsubsection{Bank Specific Variables}

Bank operating costs: In general, one would expect banks to seek to cover their operating costs by increasing net interest margin. Thus, we expect the variable to have a positive impact on NIM. We express bank operating costs as a ratio of total assets. We also include Bank credit risk as an explanatory variable as banks may compensate for the credit risk they bear by increasing their margins. In principle, it is the provision for bad and doubtful loans that more closely suggests the quality of the loan portfolio. Unfortunately, lack of data precluded the use of this ratio. Following Maundos and Fernández de Guevara (2004), we use as alternative measure of bank risk, the ratio of bank loans to total assets. The degree of bank risk aversion is also included as an independent variable. A more risk averse bank will have more equity in its capital structure in order to be sure that it has funds against which to write off losses that might occur. Nevertheless, it must earn enough returns to cover the required rate of return by shareholders. Consistent with this reasoning, such a bank will charge higher margins. Our measure of risk aversion is the ratio of shareholders equity to total assets. In this implementation this variable serves another purpose: it controls for the impact of individual country regulation in respect of the capital adequacy ratio of banks. (Individual country guidelines may deviate from those proposed by the Basel Committee on Banking Supervision.)

Quality of bank management also influences interest rate margins. Firms with superior management should be more efficient in managing resources and will thus incur lower costs per unit of revenue, which could lead to higher profits. Thus, the variable that measures bank operating cost per unit of revenue is an indicator of management efficiency. Alternatively, such banks may charge lower margins if efficiency savings are passed on to customers. This could result in such banks gaining large market share that might result in high levels of concentration. Berger (1995) has suggested that the way to test for these so called efficient structure hypothesis is by introducing concentration, efficiency, and market share as explanatory variables of relative interest rate margins.

We include Size of bank operations is a determinant of net interest margin as large-scale operations may influence NIM through lowering average costs and hence, higher profits. Alternatively, banks may pass on cost savings to customers in the form of lower margins. The usual measures of this indicator are total assets, total deposits or total loans but these variables are reported in local currencies rendering them unsuitable for cross-country analysis such as this. We overcome this hurdle by standardizing the total assets of each bank by the gross domestic product (GDP) of each country both of which are reported in current local currency units by the World Development Indicators. 


\subsubsection{Industry Characteristics}

We include in the study are industry structure and opportunity cost of non-earning bank reserves as industry variable. The literature notes that bank profits (margins) are relatively higher in concentrated markets. The usual measure of industry concentration is the Herfindahl-Hirshman index, computed as the sum of the squares of individual bank's market share of total industry assets, deposits or loans. Total industry asset figures were not readily available. We use the ratio of a bank's total assets to GDP reported in domestic currency to proxy for the bank's market share. (Note 7) We also include the Opportunity cost of non-earning bank reserves (primary reserves) as an explanatory variable. In many jurisdictions, banks are required by law to set aside a percentage of the deposits they mobilize as non-earning reserves against contingencies to provide liquidity cushion. Liquidity reserve requirements are a burden on the industry, impacting negatively on profitability and must therefore be passed on to customers in the form of wider margins. We measure this variable as the ratio of cash and near cash items to total bank assets. In this implementation, this variable serves another purpose, it controls for the impact of individual country's regulation in respect of the primary reserves ratio.

\subsubsection{Economy-wide Variables}

Unstable macroeconomic and policy environment is perceived as risky and banks may compensate for it by requiring wider margins. Our proxies for the macroeconomic environment in which banks operate are the rates of inflation and the volatility in the Treasury bill rates. The volatility of interest rates is hypothesized to impact bank margins positively as banks may have to borrow to make loans whenever requests for loans arrive and banks do not have enough deposits. Conceivably, other measures of interest rate risk may be used, but for many transition and other developing economies dependable money market rates are not available. Treasury bill rates are the ones most readily available. Higher volatility should translate to higher margins, as will unstable inflation. The bank management literature suggests that interest rate risk and credit risk are not uncorrelated. Here we capture this potential relationship by interacting credit risk with interest rate risk measures.

\subsection{Results: Overall Sample}

We present the results of our cross sectional regression of the factors that explain post privatization NIM for our full sample of banks in Table 4 Panel A. The columns labeled (1) and (1)'present results using the means of the variables, while the columns labeled (2) and (2)' present the results when the medians of the values are used in the regressions. Panel A shows the results of the regression whereas Panel B shows the impact of variables with significant quadratic terms. Preliminary tests suggested the presence of heteroskedasticity, so we estimated all specifications using the Eicker-White heteroscedasticity-consistent standard error technique.

In each case, the two regressions (mean and median regressions) fit the data well. However, the specification tests suggest that the medians of the variables provide a somewhat better fit (i,e., higher adjusted R-squared and higher log likelihood ratio) than the means. This is in general agreement with the fact that ratio distributions tend to be heavy-tailed. Median based methods tend to offer a way to cope with this problem (Brody et al., 2002). In addition, we observe that for a number of the variables the relationship is quadratic as the quadratic forms of these variables are significant. For example in (1), both OPEXP and OPEXP-squared, and EQTA and EQTA-squared enter the specification as explanatory variables that significantly impact NIM. To gain insight into the overall impact of variables whose quadratic terms are also significant, we took partial derivatives of NIM with respect to these variables and evaluated the resulting expressions at the sample means and/or medians. Using OPEXP and OPEXP-squared in (1) as an example, $\partial($ NIM $) / \partial(O P E X P)=\alpha_{1}+2 \alpha_{2}$ OPEXP, which is then evaluated at the sample mean, where $\alpha_{1}$ and $\alpha_{2}$ are the estimated coefficients in Table 4a. Table $4 \mathrm{~b}$ presents the partial derivatives of NIM with respect to the variables with significant quadratic terms (p-values less than 0.1 ) evaluated at the sample mean for (1) and (1)', and at sample medians for (2) and (2)'.

The discussion of regression coefficients refers to both Panels A and B of Table 4. For example, the results presented in Panel A suggest that for the mean NIM regression (1) and median NIM regression (2), OPEXP and its quadratic coefficients have p-values less than 0.01 . Turning to Table $4 \mathrm{~b}$, we see that their combined impact in (1) is 0.1714 and 1.5172 in (2). In fact, operating expenses have a positive impact on NIM in all four regressions and are significant in three. This result is consistent with the expectation that banks pass on increasing operating expenses in the form of interest rate spreads. Referring to Panel A, the linear form of LOANS (credit risk) is significant at $10 \%$ in (1). In (1)' the quadratic form has p-value less than 0.05 . In the median NIM regression (2)' both the quadratic and linear forms have $p$-values less than 0.1. Proceeding as before, we observe that the impact of credit risk on NIM is 0.0148 for regression (1) in Panel A. For the impact of the quadratic term in (1)' and of its linear and quadratic terms in (2)' we refer to Panel B, where the combined impact is 0.0466 in (1)' and 0.0170 in (2)'. Angbazo (1997), who first argued 
for the inclusion of credit risk in this type of analysis, made the case for a positive coefficient since banks with poor portfolios would be expected to charge higher margins. Subsequently, researchers have found both positive (Maudos and Fernádez de Guevera, 2004, and Chirwa and Mlachila, 2004) and negative (Williams, 2007, and Aboagye et al., 2008) coefficients.

$<$ Insert Table 4 Here $>$

The quadratic and linear forms of EQTA, our indicator of risk aversion, enter all four regressions and are significant. The result presented in Panel B indicates that the impact of this variable is positive in all equations. This is consistent with expectation that the more risk averse a bank is, the higher the spread and the greater the likelihood that it will seek to compensate suppliers of equity. MGMT, our indicator of managerial quality has mixed impact as it has positive and significant (p-values less than 0.01) impact on NIM in the regression using means of variables but negative impact in the regressions using medians. The median results are consistent with those of Angbazo (1997) who expected a negative coefficient for this variable on the grounds that superior management would translate to lower interest rate spreads. It is important to note, however, that bank management may not pass on savings arising from its superior management of bank to customers.

The quadratic and linear forms of CASH, the indicator of liquidity, are significant in (1)' and (2)' with p-values less than 0.05. We observe from Panel B that its impact is positive. In principle, a positive sign is expected as banks compensate for staying liquid by charging wider margins. TAGDP, our proxy for scale of operations, has small negative coefficients which are significant at the $10 \%$ level in (1)' only. (Note 8) TAGDP-squared, our proxy for bank concentration is small, positive albeit not significant. Our indicator of volatility in interest rate markets, VOLAT, is positive in all equations, as predicted by theory, but they are significant (p-values less than 0.1) in the mean equations only. The impact of INFL is positive in all regressions and is significant in all but one regression. This finding is consistent with banks responding to uncertainties about interest rates by increasing NIM. The interaction of VOLAT and INT has negative impact on NIM and is significant in all cases.

We also re-estimate the regression using Developeddummy to capture the difference in the post privatization NIM between the developed and developing countries. The variable takes on a value of 1 for privatized banks in the OECD countries and zero for those in the developing countries. Though not shown here, the developed dummy variable is not statistically significantly.

In addition, we noted that Eastern Europe had a reasonable representation of banks in our sample, but not enough observations to support a regression analysis (with sufficient statistical power). Therefore, we re-estimated the regression incorporating Eastern European dummy variable, E, (that takes a value of 1 if bank is located in Eastern Europe, and 0 otherwise), to identify banks from this region. Though not reported here for brevity reasons, many slope coefficients of the interaction of the Eastern European dummy and explanatory variables differ significantly from the slope coefficients of the rest of the sample. For example, we find that Eastern European Banks' operating expenses are positive and significant as predicted by theory in both the means and median regressions. Quality of management has negative and significant impact, a finding that is consistent with narrowing margins. Contrary to what theory predicts however, we find that measures of credit risk (namely, risk-aversion and liquidity) have negative signs in the two regressions.

\subsection{Robustness Test}

To obtain a sense of the robustness of our findings, we specified an alternate measure of interest rates spread, namely the difference between the interest income (II) to total loans (L) ratio and the interest expense (IE) to deposits (D) ratio, i.e. (II/L-IE/D). Brock and Rojas-Suarez (2000) refer to this as a narrow measure of interest rate spread. As we did for net interest margins, we first tested for differences in indicators of central tendency in the pre- and postprivatization values of this measure. The results which are reported in Table 5 suggest that for the full sample, there is no statistically significant difference between the pre- and post-privatization means and medians of (II/L-IE/D). For privatized banks in developing countries however, the post-privatization mean NIM is significantly lower than the pre-privatization mean NIM at the $10 \%$ level. These results should however be interpreted with caution given that means can be influenced significantly by outliers.

$<$ Insert Table 5 Here>

Turning to the median results, we find that consistent with our main results, the post-privatization median (II/L-IE/D) ratio for the banks in developing countries is lower than their pre-privatization NIM at the 5\% level. Similarly, consistent with the main results, the post privatization NIM for the privatized banks in the developed countries is not statistically different from that of the pre-privatization period. As noted earlier for our main results, the difference in 
the results could be due to competition as the results are consistent with the assertion that lack of competition in developing countries might have kept margins artificially high in the pre-privatization period. Interestingly, and consistent with the foregoing assertion, we find from the results reported in the last two column of Table 5 that the median pre-privatization NIM for the privatized banks in the developing countries of 0.106 is statistically higher than that of the banks in the developed countries at the $1 \%$ level ( $\mathrm{t}$-statistics=3.71). While the post-privatization NIM for banks in the developing countries is still higher than that of their counterparts in the developed world (the difference of $4.6 \%$ is statistically significant at $1 \%$ ), the difference in the NIM has reduced in the post privatization period. This finding is consistent with the median results documented earlier, and they imply that consumers in developing countries have benefited from privatization although they still face high margins.

Next, using mean and median of (II/L-IE/D) as the dependent variable, we re-estimated the cross sectional regression for the full sample and present the results in Table 6. Panel A indicates that both the linear and quadratic terms of a number of variables significantly impact our alternative measure of interest rate spread (II/L-IE/D) just as they do for NIM (Table 4). To obtain the overall impact of such variables, we take partial derivatives and evaluate at the sample means and medians and present the results in Panel B. In sum, using (II/L-IE/D) as the variable of interest yields results that are broadly similar to those found for NIM in a number of respects and provide reasonable robustness check. The significance and direction of the impacts of operating expenses and liquidity on NIM and $(\mathrm{II} / \mathrm{L}-\mathrm{IE} / \mathrm{D})$ are in the same direction.

$<$ Insert Table 6 Here>

\section{Summary and Conclusion}

Most studies on bank privatization examine the pre- and post-privatization operating performance and long term stock market performance of privatized banks and document significant improvements in performance. An area of inquiry that has not received much attention in the literature is how consumers have fared under bank privatization. Privatization and the attendant liberalization of financial markets are expected to lead to more competition as the banking environment becomes more contestable. It is also reasonable to surmise that as a consequence of the relaxation of entry barriers in the banking sector and increase in competition, borrowing rates could decline and deposit rates could increase, thus leading to a narrowing of the interest rate margins. On the other hand, it is possible that increased competition could actually increase margins. When faced with increased competition, threatened privatized banks, which had hitherto enjoyed monopoly status and government subsidies, may attempt to recoup lost subsidies by increasing lending rates and or/reducing deposit rates in order to survive. Also, state control of banks could have kept margins artificially narrow in the pre-privatization period, in which case interest rate margins can widen in the post privatization period to reflect market condition. Thus, whether or not consumers have benefited from bank privatization is an empirical question. In this paper, we assess how consumers have fared in banking privatization.

We find that for our sample of privatized banks, the post-privatization median NIM is significantly higher than the pre-privatization NIM, suggesting that on the whole bank customers have not benefited from bank privatization. Although the sample as a whole experienced higher post privatization margins, we observe differential effects of bank privatization. The results show that for developing countries, the NIM has reduced after privatization whereas the NIM has increased for the developed countries sample. Thus the increase in the post privatization NIM observed for the full sample is therefore driven by the developed countries sample. Similarly, in the post privatization period the median bank in the developing countries has a higher NIM than that in the developed countries. However the difference in NIM between the two sub-samples is smaller in the post privatization period than in the pre-privatization period. Although the net interest margin in developing countries has reduced in the post privatization period, consumers still pay more for banking services than their counterparts in the developed world. The difference in NIM between the two subsamples has however reduced in the post privatization period. Lack of competition does not explain our main finding of increase in NIM in the post privatization period because the banking sector in the developed countries, where bank margins have increased, is more competitive than in the developing countries. Rather, the results appear to support the conjecture that perhaps margins were kept artificially low in the pre privatization period and that the higher post privatization margins in the developed countries reflect market conditions.

Our cross sectional analysis of net interest margin shows that banks with higher operating expenses have higher net interest margins, suggesting that consumers would benefit more if they direct their businesses to banks with lower operating margins. As a consequence many more banks will find themselves having to lower their operating expenses further in other to win more customers. Also, we find that privatized banks with higher liquidity charge 
higher margins; and those with improved managerial efficiency tend to charge lower margins. The banks with higher credit risk have the tendency to charge higher margins. In conclusion, we document differential effects of privatization on bank customers in the developed and developing countries. Although net interest margins are still higher in developing countries than in developed countries, consumers in developing countries have benefited from reduced bank margins in the post privatization period.

\section{References}

Aboagye, A. Q. Q., S. K. Akoena, T. O. Antwi-Asare., \& A. F. Gockel. (2008). Explaining Interest Rate Spreads in Ghana. African Development Review, 20, 378-399. http://dx.doi.org/10.1111/j.1467-8268.2008.00190.x

Angbazo, L. (1997). Commercial Bank Net Interest Margins, Default Risk, Interest-Rate Risk, and Off-Balance Sheet Banking. Journal of Banking and Finance, 21, 55-87. http://dx.doi.org/10.1016/S0378-4266(96)00025-8

Berger, A. N. (1995). The Profit-Structure Relationship in Banking - Tests of Market-Power and Efficient Structure Hypothesis. Journal of Money Credit and Banking, 27(2), 404-435. http://dx.doi.org/10.2307/2077876

Bonin, J., I. Hasan, \& P. Wachtel. (2002). Ownership Structure and Bank Performance in the Transition Economies of Central and Eastern Europe: A Preliminary Report. Working Paper, New York University.

Boubakri, N., J. Cosset, K. Fischer, \& O. Guedhami. (2005). Privatization and Bank Performance in Developing Countries. Journal of Banking and Finance, 29, 2015-2041. http://dx.doi.org/10.1016/j.jbankfin.2005.03.003

Braz, J. (1999). Bank (Re)privatization in Portugal. Paper presented at World Bank/Federal Reserve Bank of Dallas Conference on Bank Privatization, Washington, DC, March.

Brocks, P. L., \& L. Suarez. (2000). Understanding the Behavior of Bank Spreads in Latin America. Journal of Economic Development, 63, 113-134. http://dx.doi.org/10.1016/S0304-3878(00)00102-4

Brody, J. P., B. A. Williams, B. J. Wold, \& S R. Quake. (2002). Significance and statistical errors in the analysis of DNA microarray data. Proc Natl Acad Sci USA, 99(20), 12975-12978. http://dx.doi.org/10.1073/pnas.162468199

Chirwa, E. W., \& M. Mlachila. (2004). Financial Reforms and Interest Rate Spreads in the Commercial Banking System in Malawi. IMF Staff Papers, 51, 96-122.

Clarke, G. R. G., R. Cull, \& M. J. Fuchs. (2007). Bank Privatization in Sub-Saharan Africa: The Case of Uganda Commercial Bank, World Bank Working Paper 4407.

Cornett, M. M., Guo, L., Khaksari, S., \& Tehranian, H. (2003). The Impact of Corporate Governance on Performance Differences in Privately-Owned Versus State-Owned Banks: An International Comparison. Working Paper, Boston College.

Dewenter, K., \& P. H. Malatesta. (2000). State-Owned and Privately-Owned Firms: An Empirical Analysis of Profitability, Leverage, and Labour Intensity. American Economic Review, 91, 320-334. http://dx.doi.org/10.1257/aer.91.1.320

Djankov, S., \& P. Murrell. (2002). Enterprise Restructuring in Transition: A Quantitative Survey. Journal of Economic Literature, 40, 739-792. http://dx.doi.org/10.1257/002205102760273788

Flamini, V., C. McDonald, \& L. Schumacher. (2009). The Determinants of Commercial Bank Profitability in Sub-Saharan Africa. IMF Working Paper WP/09/15.

Ho, T., \& A. Saunders. (1981). The Determinants of Bank Interest Margins: Theory and Empirical Evidence. Journal of Financial and Quantitative Analysis, 26, 581-602. http://dx.doi.org/10.2307/2330377

La Porta, R., F. Lo'pez-de-Silanes, A. Shleifer, \& R. W. Vishny. (2002). Investor Protection and Corporate Valuation. Journal of Finance, 57, 1147-1170. http://dx.doi.org/10.1111/1540-6261.00457

Maudos, J., \& J. Fernández de Guevara. (2004). Factors Explaining the Interest Margin in the Banking Sectors of the European Union. Journal of Banking and Finance, 28, 2298-2281. http://dx.doi.org/10.1016/j.jbankfin.2003.09.004

McShane, R. W., \& I. G. Sharpe's. (1985). A Time Series/Cross Section Analysis of the Determinants of Australian Trading Bank Loan/Deposit Interest Margins: 1962-1981. Journal of Banking and Finance, 9, 115-136. http://dx.doi.org/10.1016/0378-4266(85)90065-2

Megginson, W. L. (2005). The Economics of Bank Privatization. Journal of Banking and Finance, 29, 1931-1980. http://dx.doi.org/10.1016/j.jbankfin.2005.03.005

Megginson, W.L., Nash, R.C., \& van Randenborgh, M. (1994). The financial and operating performance of newly privatized firms: An international empirical analysis. Journal of Finance, 49, 403-452. http://dx.doi.org/10.1111/j.1540-6261.1994.tb05147.x 
Nakane, M.I., \& D. B. Weintraub. (2005). Bank Privatization and Productivity: Evidence for Brazil. Journal of Banking and Finance, 29, 2259-2289. http://dx.doi.org/10.1016/j.jbankfin.2005.03.015

Nellis, J. (1999). Time to Rethink Privatization in Transition Economies. Finance and Development, 36(2), June.

Otchere, I. (2005). Do privatized banks in middle- and low-income countries perform better than Rival banks? An intra-industry analysis of bank privatization. Journal of Banking and Finance, 29, 2067-2093. http://dx.doi.org/10.1016/j.jbankfin.2005.03.001

Otchere, I. (2009). Competitive and value effects of bank privatization in developed countries. Journal of Banking and Finance, 33, 2373-2385. http://dx.doi.org/10.1016/j.jbankfin.2009.06.014

Saunders, A., \& L. Schumacher. (2000). The Determinants of Bank Interest Rate Margins: An International Study. Journal of International Money and Finance, 19, 813-832. http://dx.doi.org/10.1016/S0261-5606(00)00033-4

van de Walle, N. (1989). Privatization in Developing Countries: A Review of the issues. World Development, 17, 601-615. http://dx.doi.org/10.1016/0305-750X(89)90062-4

Verbrugge, J.A., W. L. Megginson, \& W. L. Owens. (1999). State Ownership and the Financial Performance of Privatized Banks: An Empirical Analysis. Paper presented at World Bank/Federal Reserve Bank of Dallas Conference on Bank Privatization, Washington, DC, March.

Williams, B. (2007). Factors Determining Net Interest Margins in Australia: Domestic and Foreign Banks. Financial Markets, Institutions \& Instruments, 16(3), 145-166. http://dx.doi.org/10.1111/j.1468-0416.2007.00122.x

World Bank. (2008). Public Policy for the Private Sector - Privatization Trends. Public Policy Journal, Note 317 , January. [Online] Available: http://rru.worldbank.org/PublicPolicy (November 2008)

Zinnes, C., Y. Eilat, \& J. Sachs. (2001). The Gains from Privatization in Transition Economies: Is Change of Ownership Enough? IMF Staff Papers, 48, Special Issue, 146-170.

\section{Notes}

Note 1. Pryke (1982) and Boardman and Vining (1989) cite the lack of competition as one of the reasons for the relatively poor performance of the public enterprises.

Note 2. Other reasons why governments privatize crown corporations is the desire to raise revenue for the state, promote economic efficiency, reduce government interference in the economy, promote wider share ownership, and to develop the capital markets.

Note 3. Claessens et al (2009) argue that in developing countries due to institutional weakness, such as poor informational and institutional infrastructure and weak contracting environment, access to credit by some segments of the society is limited. In such environments, competition can create a bifurcated market, one where large (international) banks will concentrate on the large corporations, serving them with a variety of products using domestic and international platforms, and one that caters to the small and medium size firms and households. Foreign bank entry and the attendant cross border capital flows have been found to increase access especially for selected groups of borrowers, e.g. large corporations that already had preferential access especially in developing countries.

Note 4. We recognize that combining data from countries that may have different accounting standards and banking laws may pose econometric challenges. It is in this regard that we restricted our bank data sources to Datastream and Bloomberg databases. These databases are known to standardize the data that they report for accounting and other differences.

Note 5. Each bank is countered only once. For example, a state-owned bank whose shares were sold to the public on three different dates counts as one bank.

Note 6. Since financial deregulation is often adopted along with other efficiency enhancing-measures, there could be reverse causality issues or omitted factors. This makes it difficult to identify the direction of causality and to disentangle the effects of financial reforms from those of other measures. These issues apply to most of the studies on financial liberalization and reform analysis.

Note 7. Thus, the ratio of a bank's total assets to GDP, both reported in local currency, proxies that banks market share, granted that GDP and industry total assets are of different magnitudes, but changes in these two measures(which are what are important in regression analyses) are closely related.

Note 8. A number of proxies have been used in the literature with mixed results - Williams (2007) used measures of retail activity and found positive but insignificant coefficients; Maudos and Fernández de Guevera (2004) used measures of bank size and found negative and significant coefficients; Chirwa and Mlachila (2004) used market share of deposits and found the coefficient to be negative and insignificant, while Aboagye et al. (2008) found positive and significant coefficients using total assets. 
Table 1. Summary of basic data on some privatized banks contained in our sample

\begin{tabular}{lccc}
\hline Region & No. of Privatized Banks & $\begin{array}{c}\text { Amount of capital offered per } \\
\text { average bank in USD millions }\end{array}$ & $\begin{array}{c}\text { \% of average bank } \\
\text { offered }\end{array}$ \\
\hline High Information Countries & 22 & 1,115 & 42.3 \\
Eastern Europe & 11 & 199 & 41.3 \\
Africa & 7 & 60 & 42.3 \\
Latin America & 6 & 801 & 64.5 \\
\hline
\end{tabular}

Table 2. Pre- and Post-privatization summary results

\begin{tabular}{lcc}
\hline & $\underline{\text { Mean }}$ & $\underline{\text { Median }}$ \\
Pre-privatization & 0.033 & 0.023 \\
Post-privatization & 0.032 & 0.033 \\
Difference (post-pre) & 0.001 & 0.01 \\
t-statistic (z-statistic for median) & $(-0.05)$ & $(2.17)^{* *}$ \\
p-value & 0.9 & 0.03 \\
\hline
\end{tabular}

This table presents the mean and median operating performance of our privatized banks sample. The t-statistic and $z$-statistic are used to measure statistical significance for the difference in mean and median NIM tests, respectively. The symbols $* * *, * *$ and $*$ indicate statistical significance at the $1 \%, 5 \%$, and $10 \%$ level respectively.

Table 3. Differential results

\begin{tabular}{lccc} 
Panel A: Differences in Mean Net Interest Margin & $\begin{array}{c}\text { Developing } \\
\text { Countries (a) }\end{array}$ & $\begin{array}{c}\text { Developed } \\
\text { Countries (b) }\end{array}$ & $\begin{array}{c}\text { (a-b) } \\
\text { Difference }\end{array}$ \\
\hline Pre-privatization & 0.045 & 0.027 & 0.018 \\
Post-privatization & 0.043 & $0.20)^{* *}$ \\
& & & 0.019 \\
Difference (post-pre) & -0.002 & -0.003 & $(4.36)^{* * *}$ \\
t-statistic & $(-0.29)$ & $(-0.85)$ & 0.001 \\
p-value & 0.74 & 0.43 & $(0.07)$ \\
\hline Panel B: Differences in Median Net Interest Margin & & 0.47 \\
\hline & Developing & Developed & $(\mathrm{a}-\mathrm{b})$ \\
& Countries (a) & Countries (b) & Difference \\
\hline Pre-privatization & 0.039 & 0.021 & 0.018 \\
& & & $(2.14)^{* *}$ \\
Post-privatization & 0.036 & 0.024 & 0.012 \\
& & & $(4.01)^{* * *}$ \\
Difference (post-pre) & -0.003 & 0.003 & -0.006 \\
z-statistic & $(-0.09)$ & $(0.79)$ & $(-0.09)$ \\
p-value & 0.93 & 0.43 & 0.93 \\
\hline
\end{tabular}

This table presents the results of difference in net interest margin for the privatized banks in developed and developing countries for the pre- and post-privatization period. Panel A shows the difference in mean test for the sample whilst Panel B shows the difference in median test. The t-statistic and z-statistic are used to measure statistical significance for the difference in mean and median NIM tests, respectively. The symbols ***,** and * indicate statistical significance at the $1 \%, 5 \%$, and $10 \%$ level, respectively. 
Table 4. Cross sectional regression results

\begin{tabular}{|c|c|c|c|c|}
\hline \multirow{2}{*}{$\begin{array}{l}\text { Panel A: regression results } \\
\text { Variables }^{1}\end{array}$} & \multicolumn{2}{|c|}{ Mean NIM } & \multicolumn{2}{|c|}{ Median NIM } \\
\hline & -1 & (1) ' & -2 & (2) ' \\
\hline \multirow{2}{*}{ OPEXP } & $0.1996 * * *$ & 0.0081 & $1.8033^{* * *}$ & $0.5993 * * *$ \\
\hline & -2.6454 & -1.583 & -4.8141 & -3.2066 \\
\hline \multirow{2}{*}{ OPEXP-squared } & $-0.2370 * * *$ & & $-8.3083 * * *$ & \\
\hline & $(-2.6693)$ & & $(-2.9092)$ & \\
\hline \multirow{2}{*}{ LOANS } & $0.0148^{*}$ & -0.0143 & 0.0134 & $-0.0724 *$ \\
\hline & -1.6092 & $(-0.9733)$ & -0.8659 & $(-1.7456)$ \\
\hline \multirow{2}{*}{ LOANS-squared } & & $0.0403 * *$ & & $0.0723 * *$ \\
\hline & & -2.4276 & & -2.0268 \\
\hline \multirow{2}{*}{ EQTA } & $0.1165^{*}$ & $0.1166^{*}$ & $0.1644 * * *$ & $0.1962 * * *$ \\
\hline & -1.6862 & -1.6505 & -2.5948 & -3.1433 \\
\hline \multirow{2}{*}{ EQTA-squared } & $-0.1202^{*}$ & $-0.180^{*}$ & $-0.1464 * * *$ & $-0.1796^{* * *}$ \\
\hline & $(-1.8510)$ & $(-1.7941)$ & $(-2.5397)$ & $(-3.1514)$ \\
\hline \multirow{2}{*}{ MGMT } & $0.0398 * * *$ & $0.0715^{* * *}$ & $-0.0514 * *$ & -0.0007 \\
\hline & -2.8177 & -5.5222 & $(-2.4201)$ & $(-0.0375)$ \\
\hline \multirow{2}{*}{$\mathrm{CASH}$} & -0.0248 & $0.08815^{* *}$ & -0.0191 & $0.0760^{* *}$ \\
\hline & $(-1.3533)$ & -2.4578 & $(-0.8312)$ & -2.1776 \\
\hline \multirow{2}{*}{ CASH-squared } & & $-0.2185^{* * *}$ & & $-0.0760 * *$ \\
\hline & & $(-4.0413)$ & & $(-2.1242)$ \\
\hline \multirow{2}{*}{ TAGDP } & -0.0293 & $-0.0434^{*}$ & -0.0096 & -41 \\
\hline & $(-1.2946)$ & $(-1.7895)$ & $(-0.3808)$ & $(-0.1770)$ \\
\hline \multirow{2}{*}{ TAGDP-squared } & 0.02666 & 0.0318 & 0.0179 & 0.0033 \\
\hline & -0.7868 & -0.9141 & -0.5158 & -0.101 \\
\hline \multirow{2}{*}{ VOLAT } & $0.2655 * *$ & $0.2266^{*}$ & 0.2546 & 0.179 \\
\hline & -1.9979 & -1.787 & -1.5572 & -1.0748 \\
\hline \multirow{2}{*}{ INFL } & $0.1025 * *$ & $0.1228^{* * *}$ & 0.045 & $0.0761 * *$ \\
\hline & -2.1853 & -2.7819 & $(1.2959$ & -2.0437 \\
\hline \multirow{2}{*}{ CRD_INT } & $-0.7550 * *$ & $-0.6336^{*}$ & $-0.6720^{* *}$ & $-0.5071^{*}$ \\
\hline & $(-2.0857)$ & $(-1.8244)$ & $(-2.1738)$ & $(-1.6742)$ \\
\hline Adjusted $\mathrm{R}^{2}$ & 0.46 & 0.45 & 0.7 & 0.68 \\
\hline Degrees of freedom & 63 & 62 & 63 & 62 \\
\hline Log likelihood & 214.75 & 214.52 & 229.95 & 227.72 \\
\hline \multicolumn{5}{|c|}{$\begin{array}{l}\text { Panel B: Impact of variables with significant quadratic terms holding other variables constant (partial derivativ } \\
\text { evaluated at their sample means and medians. }\end{array}$} \\
\hline Variable & -1 & $(\mathbf{1})^{\prime}$ & -2 & $(2)^{\prime}$ \\
\hline OPEXP & 0.1714 & & 1.5172 & \\
\hline LOANS & & 0.0466 & & 0.017 \\
\hline EQTA & 0.0901 & 0.0906 & 0.1398 & 0.1662 \\
\hline CASH & & 0.0449 & & 0.0588 \\
\hline
\end{tabular}

This table presents the results of the regression of net interest margin of privatized banks on a number of explanatory variables. Panel A shows that main results whilst Panel B shows the impact of variables with significant quadratic terms holding other variables constant (partial derivatives) evaluated at their sample means and medians .T-values in parenthesis below coefficient estimates. The symbols*, ${ }^{* *},{ }^{* * *}$ represent significance at $10 \%$, and $1 \%$ respectively. 
Table 5. Robustness test

\begin{tabular}{|c|c|c|c|c|c|c|}
\hline \multicolumn{7}{|l|}{ Panel A: Full Sample } \\
\hline & \multicolumn{3}{|c|}{ Mean } & \multicolumn{2}{|l|}{ Median } & \\
\hline \multicolumn{2}{|l|}{ Pre-privatization } & \multicolumn{2}{|l|}{0.073} & \multicolumn{2}{|l|}{0.37} & \\
\hline Post-privatization & & \multicolumn{2}{|l|}{-0.002} & \multicolumn{2}{|l|}{0.38} & \\
\hline Difference (post-pre) & & \multicolumn{2}{|l|}{-0.075} & \multicolumn{2}{|l|}{0.01} & \\
\hline t- or z-statistic & & \multicolumn{2}{|l|}{$(-0.92)$} & \multicolumn{2}{|l|}{-0.33} & \\
\hline p-value & & \multicolumn{2}{|l|}{0.35} & \multicolumn{2}{|l|}{0.88} & \\
\hline \multicolumn{7}{|c|}{ Panel B: Differential impact: Developing vs. Developed countries } \\
\hline & $\begin{array}{l}\text { Developing } \\
\text { countries (a) }\end{array}$ & $\begin{array}{l}\text { Mean } \\
\text { Developed } \\
\text { countries (b) }\end{array}$ & $\begin{array}{l}\text { Difference } \\
(\mathrm{a}-\mathrm{b})\end{array}$ & $\begin{array}{l}\text { Developing } \\
\text { countries (c) }\end{array}$ & $\begin{array}{l}\text { Median } \\
\text { Developed } \\
\text { countries (c) }\end{array}$ & $\begin{array}{l}\text { Difference } \\
\text { (c-d) }\end{array}$ \\
\hline Pre-privatization & 0.215 & 0.007 & $\begin{array}{l}0.208 \\
(1.21)\end{array}$ & 0.106 & 0.023 & $\begin{array}{l}0.083 \\
(3.71)^{* * *}\end{array}$ \\
\hline Post-privatization & 0.041 & -0.037 & $\begin{array}{l}0.078 \\
(0.98)\end{array}$ & 0.068 & 0.022 & $\begin{array}{l}0.046 \\
(3.81)^{* * *}\end{array}$ \\
\hline Difference (post-pre) & -0.174 & -0.044 & -0.13 & -0.038 & -0.001 & -0.037 \\
\hline t-statistic & $(-1.93)^{*}$ & $(-0.44)$ & $(-0.14)$ & $(-1.93)^{*}$ & $(-0.46)$ & $(-2.53)^{* * *}$ \\
\hline p-value & 0.07 & 0.68 & 0.44 & 0.053 & 0.64 & 0.01 \\
\hline
\end{tabular}

This table presents results for the sample using alternative measure of bans spread, namely the difference between the interest income (II) to total loans (L) ratio and the interest expense (IE) to deposits (D) ratio (II/L - IE/D). Panel A shows the differences in (II/L - IE/D) pre- and post privatization using sample means and medians while Panel B shows the differential impact of the variable for the sample banks in developed and developing countries. 
Table 6. Additional robustness test

\begin{tabular}{|c|c|c|}
\hline \multicolumn{3}{|c|}{ Panel A: Main regression results } \\
\hline Variable & Regression using means & Regression using medians \\
\hline \multirow{2}{*}{ OPEXP } & $1.2616^{*}$ & $11.3661^{* * *}$ \\
\hline & -1.7275 & -2.5576 \\
\hline \multirow{2}{*}{ OPEXP-squared } & $-1.5801^{*}$ & $-58.5104 *$ \\
\hline & $(-1.8038)$ & $(-1.7480)$ \\
\hline \multirow{2}{*}{ LOANS } & 0.1114 & $-0.2360 * *$ \\
\hline & -0.6824 & $(-2.3774)$ \\
\hline \multirow{2}{*}{ EQTA } & -0.113 & 0.1334 \\
\hline & $(-0.6294)$ & -1.4618 \\
\hline \multirow{2}{*}{ MGMT } & 0.0666 & $-0.4713^{* *}$ \\
\hline & -0.3272 & $(-2.4418)$ \\
\hline \multirow{2}{*}{ CASH } & $0.5577 * *$ & 0.42396 \\
\hline & -1.9661 & -1.5609 \\
\hline \multirow{2}{*}{ TAGDP } & $0.8904 * *$ & $0.6163 * *$ \\
\hline & -2.1331 & -2.3641 \\
\hline \multirow{2}{*}{ TAGDP2 } & $-1.3938 * *$ & $-0.8407 * *$ \\
\hline & $(-2.3177)$ & $(-2.1904)$ \\
\hline VOLAT & & $\begin{array}{c}-5.4688 * * \\
(-1.9475)\end{array}$ \\
\hline \multirow{2}{*}{ VOLAT-squared } & $-40.9413 * * *$ & $-21.4688 * *$ \\
\hline & $(-2.5311)$ & $(-2.1904)$ \\
\hline \multirow{2}{*}{ INFL } & $-6.2915^{* * *}$ & $-4.5904 * * *$ \\
\hline & $(-2.5651)$ & $(-3.8471)$ \\
\hline \multirow{2}{*}{ INFL-squared } & $33.9269 * * *$ & $21.1684 * * *$ \\
\hline & -2.7778 & -4.345 \\
\hline \multirow{2}{*}{ CRD_INT } & -3.8633 & $8.6821^{* * *}$ \\
\hline & $(-0.9171)$ & -2.673 \\
\hline Adjusted R-squared & 0.46 & 0.52 \\
\hline Degrees of Freedom & 63 & 62 \\
\hline Log likelihood & 2.23 & 38.72 \\
\hline
\end{tabular}

Panel B: Impact of variables with quadratic terms on (II/L - IE/D) holding other variables constant (partial derivatives) evaluated at their sample means and medians.

\begin{tabular}{lcc}
\hline Variable & Regression using means & Regression using medians \\
OPEX & 1.0737 & 9.3513 \\
TAGDP & 0.5816 & 0.5036 \\
VOLAT & -2.454 & -6.2365 \\
INFL & -0.8452 & -2.0171 \\
\hline
\end{tabular}

This table presents the results of the regression of our alternative measure of bank spread (II/L-IE/D) of privatized banks on a number of explanatory variables. OPEXP is operating expense, EQTA is the ratio of shareholder equity to total assets and is our indicator of risk aversion; CASH is our variable for liquidity, MGMT, LOANs, VOLAT is the volatility of Treasury bill rate, INFL is inflation, CRD_INT is bank credit risk; TAGDP is total assets of banks scaled by GDP. Panel A shows that main results whilst Panel B shows the impact of variables with quadratic terms on (II/L - IE/D) holding other variables constant (partial derivatives) evaluated at their sample means and median. T-values are in parenthesis below coefficient estimates. The symbols*, **,*** represent significance at $10 \%$, and $1 \%$ respectively. 